\title{
Analysis of Earthquake Park Design Criteria: Cases in Atașehir and Topkapı Parks, Istanbul
}

\author{
Gökçen Firdevs Yücel Caymaz ${ }^{1 *}$, Hümeyra Komar² \\ 1 Istanbul Aydın University, Faculty of Architecture and Design, Istanbul, Turkey \\ 2 Institute of Science, Istanbul Aydın University, Istanbul, Turkey
}

Received 2021-05-01; accepted 2021-06-30

\section{Keywords}

Disaster prevention parks, post-disaster, public open space, public life study, temporary urbanism.

\begin{abstract}
Earthquake parks are open spaces where sustenance, shelter and security needs required by people to sustain their daily lives after a disaster may be addressed. In this study, the use of Ataşehir and Topkapı earthquake parks as recreation areas before an earthquake and as a post-disaster park were examined from a space design aspect using on-site observations. Standards required for earthquake parks were determined, such as land location and suitability, transportation, size and function, infrastructure systems, structural and vegetative designs, whereas evaluations of these criteria were conducted at two parks. As a result of this study, it was identified that unlike traditional parks, designing earthquake parks according to site location and suitability, transportation, size and function, infrastructure systems, structural and planting design is important for post-disaster use.
\end{abstract}

\section{Introduction}

Public areas can serve as basic life support, as they can be used for emergency evacuation and rescue in the event of a possible disaster. Jayakody, Amaratunga, and Heigh (2018) emphasized the need to consider disaster management strategies along with sustainable development strategies while planning and designing public urban spaces [1]. The evacuation, medical aid, communication, shelter and food needs arising after a disaster can be met with the establishment of networks and social links in urban open areas [2].

In considering available literary studies, improvements in public spaces can have positive effects on disaster resistance [3]. It has been ascertained that interaction with vegetation, such as parks, gardens, tree planting, etc., helps individuals' resilience and resilience during disaster periods, not only through the therapeutic effects associated with psychology, but also by reviving memories [4]. Open spaces shall also be vitally important in addressing post-disaster security and housing needs [5], [6], [7]. While they enable people to come together safely after a disaster, assembly areas also meet their sustenance needs [8]. Open spaces assume the role of a 'second city' after a possible earthquake. A second city refers to an inactive open area network that becomes active after a disaster, providing areas for evacuees to assemble and seek temporary shelter [9]. As the initial evacuation point during and after urban disasters, it is vitally necessary to provide open spaces that are easily accessible from all units. Parks scattered all over the vicinity provide more opportunities as evacuation sites than a centrally located park [10]. According to a similar view in Japan, the larger the open area, the more important its perceived value for disaster prevention. For this reason, the contribution of small public areas in regards to disaster prevention is viewed as negligible [11].

According to the results of a survey published in the International Journal of Disaster Risk Reduction, it was determined that parks, plazas and good street design can improve a community's ability to survive an earthquake [12]. Not only green spaces, but also built up and undeveloped open spaces play an important role in urban seismic resilience [13].

In their 2016 study regarding how the city of Christchurch, New Zealand, recovered after the 
earthquakes of 2010 and 2011, Brand and Nicholson emphasized that the public space becomes larger, greener, more creatively flexible and transformative which is determined by its inclusion of public private boundaries [14]. Chan, DuBois, and Tidball (2015) argued that earthquake parks in New York City were important resources that bolstered neighbourhoods in their effort to avoid the adverse effects of Hurricane Sandy in 2012 [15]. Dionísio (2016) stated that even places with small open spaces would be crucial during a disaster [16].

\section{Problems in Urban Open and Green Spaces Before and After Earthquakes}

An earthquake is an unavoidable natural phenomenon that poses a great threat with the uncertainty of when it is going to strike. However, with planning measures in place, the effects of disaster-destruction can be kept to a minimum and the effects of destruction can be limited, whereby emergency response and rescue efforts can be made more effective during the aftermath with a combination of aid facilities, public spaces and shelters.

Despite being an industrialized country, Japan suffered great losses with acute evacuation and housing problems as a result of the 1995 Great Hanshin-Awaji earthquake. There were 6433 lives lost, 250000 structures demolished, with property damage of around $¥ 10$ trillion. The earthquake victims who inhabited evacuation centres for a long time due to a disruption in their flow of daily life experienced confusion due to the lack of an organized emergency evacuation system after the earthquake, the lack of concrete information about evacuation routes and areas, direction signboards. This situation suggests that it is necessary to develop evacuation routing systems and evacuation plans, prepare guidebooks that clearly indicate evacuation routes and who is responsible for evacuation. Due to the extent of damage inflicted upon infrastructure utility plants, there was a heavy demand for assembly areas where the needs of people could be addressed. Having sought asylum in private centres called 'evacuation centres,' earthquake victims were rejected by administrators in some state-managed facilities, including sanatoriums [17]. The continuation of aftershocks after the 1999 Marmara earthquake created fear in people, and people who could not enter their homes remained in undeveloped land, parks, roadsides and some green areas. The first urgent demand after the earthquake was the need for shelter. Due to insufficient open spaces, the use of rubble piles for storage at the same time has adversely affected the psychology of people. Again, the location, quantity and size of green and open areas were insufficient in the face of fire and similar problems that occurred after the earthquake, and a safe environment could not be provided.

\section{The Need for Assembling After an Earthquake}

During an earthquake, people tend to instinctively flee the building, head for open spaces in order to feel safe, to overcome the impact of the initial shock, and get together with their relatives and communicate. There should be an area near each individual's home or workplace as a precaution for safety matters such as damaged buildings after a natural disaster, continuation of aftershocks or gas leaks [18].

Emergency assembly areas constitute the assembly point in a situation that requires individuals to flee their homes. These serve as pre-evacuation areas where rescue teams are also present and information is exchanged until the temporary shelter centres are ready. The assembly areas should be a minimum $1.5 \mathrm{~m}^{2}$ per person. Open spaces, neighbourhood parks, mosques and schools are examples of emergency assembly areas [19].

Tent areas are spaces where portable tents are located in order to prevent earthquake victims from being adversely affected by weather conditions. The climate and soil structure of these areas need to be suitable for use. Since families who lost their homes after a disaster may have to remain in tents for a long-term, it is important that the tents are suitably durable for natural conditions as much as possible.

In residential areas damaged and destroyed due to the severity of the earthquake, the aim of temporary residential areas is to address the shelter needs and minimum living conditions of homeless individuals. In particular, temporary lodging areas offer basic elements such as electricity, water, food, communications and sewerage. The distances of the previously designed temporary settlement areas to health care institutions, markets and warehouses need to also be taken into consideration.

Site selection of earthquake parks in Istanbul, 859 assembly areas with a capacity of 21 million people, with a total size of 32 million square meters, was done in 39 districts. A total of 1170 open and 2662 closed temporary accommodation areas were determined, and in site selection attention was paid to ensure that the size of the open area was at least 10 thousand square metres. The areas are planned in a way that will provide short or medium-term shelter for the citizens after the disaster and support the rescue efforts.

Earthquake gathering areas are the areas where basic needs such as shelter, nutrition and health are met in order to be protected from the negative effects of a possible disaster during and after the disaster. After the earthquakes of 17 August and 12 November 1999, 470 gathering areas were determined in Istanbul within the framework of the "Disaster Emergency Action Plan"; however, according to the report of the Istanbul Metropolitan Municipality Earthquake and Natural Disaster Commission, only 77 of these areas have survived. There are objections to this 
determination from Istanbul district municipalities and various authorities, and different numbers are suggested regarding tent and container cities and other temporary accommodation areas to be established in Istanbul in case of a possible disaster.

To be more specific, earthquake gathering areas are defined as large and wide areas with infrastructure on which temporary cities can be built and where basic needs such as electricity, water, heating, shower and toilet can be met. Therefore, the determination of school gardens, parks and vacant lands, which district municipalities show as earthquake assembly areas is not significant. In addition, considering the urban texture, building quality and population factors of Istanbul, the adequacy of the gathering areas becomes more controversial. According to TUIK 2020 data, in Istanbul, which has a population of $15,519,267$ people, there are not enough areas of sufficient size and quality to meet the needs of gathering and shelter after the earthquake.

\section{Earthquake Parks}

While they meet the recreational needs of the community in daily use, these are parks which address its needs for assembly and shelter in cases when earthquake victims cannot use their houses and, unlike other assembly areas, should be set up in the city centre after a possible disaster. Easy to access and evacuate, earthquake parks should be able to be quickly organized in the event of a possible disaster by expert personnel or groups of local officials trained before the disaster. Concurrently, the fact that the business departments are planned in advance ensures the systems that need to be operated urgently are made in a timely manner [20]. The open urban areas and particularly the Monumento de la Revolucion Square and its vicinity played a key role in the rescue operations of the 1985 Mexico earthquake, one of the biggest earthquakes in the world with a magnitude of 8.4 [21]. Again, with the 7.2 magnitude Japan / Hanshin Awai Earthquake which struck in 1995, parks became a central area used for disaster recovery and reconstruction task [22].

In the aftermath of the 17 August 1999 Marmara Earthquake, it was understood that urban landscape planning and urban planning should reconsider the planning of outdoor urban green areas prior to and after the earthquake [23]. Scientists have warned that there is pent up energy along the North Anatolian Faultline in Istanbul and $a+7$ earthquake is inevitable. In line with lessons learned from previous earthquakes, a number of changes have been made over the past 20 years. Legislation regarding construction has been ratified, earthquake containers have been positioned at certain points in Istanbul, but no information about how many of them are active is made available. While parks or vacant lands are determined as assembly areas in Istanbul, they are classified as evacuation routes on the main arteries. On the other hand, some NGOs claim that the designated assembly areas do not meet the necessary criteria and that only $3 / 4$ of the designated areas have been opened for development since the 1999 Marmara Earthquake. According to AFAD, there are 2864 assembly areas in Istanbul, whereas according to TMMOB and the Chamber of Civil Engineers, there are just 77 assembly areas that meet the necessary criteria [24].

\section{The Importance of City Parks in the Aftermath of Earthquakes}

Compared to the rigidity of building and park infrastructures, parks sustain less damage and are frequently used by residents before any disaster has allowed them to become evacuation points. After the devastating impact of the Great Hanshin-Awaji Earthquake (GHAE), it was observed that many parks sustained less damage than other infrastructure. For local residents, these parks became centres where they were able to rebuild their lives. For this reason, parks act as catalysts by achieving a new norm after a disaster as well as preserving a city's culture, ecosystem and social order. Brown argued that urgent needs such as evacuation, medical aid, communications, social assembly, housing, food and water distribution are often planned in the open space of a city, and landscape architects need additional design guidelines to better support open spaces after such disasters. In the event of an earthquake parks can also prevent possible risks and liquefaction as well as fire prevention by hindering the development of unstable geological formations. The Japanese Institute for Landscape Architecture has categorized parks into six uses: (1) shortterm shelter; (2) distribution of medical and other supplies; (3) a combination of (1) and (2); (4) temporary housing; (5) storage of debris, garbage and cars; (6) less intensive use, including temporary evacuation [25].

\section{Earthquake Park Landscape Design Standards}

Site Location and Suitability

In 2014, León and March drew attention to features of an earthquake park, such as site size, slope, soil type of the land and the capacity of the site to support emergency services and infrastructure [26]. As short-term needs for housing and services expand in the days and months following a disaster, guidelines for such needs pertaining to the size of open spaces also change. For instance, at least $45 \mathrm{~m}^{2}$ per person will be needed for long-term shelter needs [27]. Another important issue in the design of earthquake 
parks is to take the climatic characteristics of the location of the land into account. The duration of hot and cold weather conditions plays a crucial role in determining indoor and outdoor designs [28].

In their 2016 study, Xu, et al. laid down seven principles regarding the location of earthquake evacuation shelters, including security, land use, nearest evacuation location, economy, appropriate transportation distance, coverage, and population capacity [29]. Shelters should be located away from potentially risky areas such as fault lines, liquefaction risk, any nearby structures that might collapse, and chemical depots. The park to be used in case of a possible earthquake should be situated near residential areas, whereas spatial distribution should be planned according to population density and the importance of the region's inhabitants to easily find their shelter. Earthquake victims should be able to reach their shelter within a short time. In a study regarding earthquake parks that was conducted by the Directorate of Earthquake Risk Management and Urban Improvement for Istanbul, there needs to be at least $250 \mathrm{~m}$ or a 15 -minute walk between the buildings to the assembly area, in line with assembly and accommodation site standards. While Masuda calculated the area to be $2 \mathrm{~m}^{2}$ / PAX in general in his 2014 study, he said that the assembly and accommodations space in Istanbul should be $1.5 \mathrm{~m}^{2}$ / PAX, and assembly and emergency accommodations space should be $3.5 \mathrm{~m}^{2} /$ PAX.

Transportation

In the aftermath of an earthquake, it is critically important to make transportation available to and from shelters and aid distribution. Damage to aid networks results in poor healthcare and serious disruption of operations during disasters. Demolished roads, buildings and bridges sever transportation routes and cause traffic congestion in densely populated cities. Earthquakes wreak havoc on residential areas, destroying buildings, structures, infrastructure, bridges, roads, and utility lines, having a detrimental impact on access networks. Thereby, the transportation duration is as important as the number and capacity of demand realized for an earthquake park [30]. It should be comfortable and easy for pedestrians to reach the park grounds via various means such as on foot, by car, bike or bus. Another important issue regarding transportation is the relationship between the park and its environs.

- Entry: Park entrances need to be visible and defined and wide enough not to interfere with the entry of emergency vehicles, such as ambulances, fire trucks.

- Roads: The presence of traffic lights along park roads to direct traffic jams and speed limits also ensures pedestrian safety. Moreover, road connections inside and outside the park need to be well-designed in order to properly direct individuals. According to the Disaster
Reduction and Human Renovation Institution (1997), avenues facing the park should be 6-m wide [25].

- Parking Lot: The parking lot where evacuees who reach the park via motor vehicle should be of sufficient size and offer easy access to the park after an earthquake. Moreover, this sufficiency is valid for vehicles transporting aid such as parking lot tools, equipment and foodstuffs as well [31].

- Helipad: Due to transportation difficulties and time limitations experienced during the disaster aftermath, aircraft such as helicopters can be utilized for longdistance transportation of casualties and medical supplies by putting into place their particular landing conditions during the disaster response phase [32].

\section{Size and Function}

For the initial 72 hours after disaster strikes, shelters are up in the air until emergency management agencies erect tents or temporary structures. Thus, many spatial structures such as gazebos, seating elements, picnic shelters can be designed to serve as emergency shelters [3]. In his research conducted in 2014, Masuda suggested that the larger the open areas, the greater the level of disaster prevention. However, he also observed that small areas were also heavily used where there was a lack of open space. Masuda also stated that small green areas of $1000-2000 \mathrm{~m}^{2}$ in size used as outdoor aftermath shelters and neighbourhood parks of $1000-3000 \mathrm{~m}^{2}$ in size would suffice as temporary shelters for up to a week. The multifunctionality of public spaces creates resilient societies by creating a culture of flexibility. The more multi-functional or hybrid parks are available in daily life, the more they will play a key role in aftermath emergency responses [33].

\section{Infrastructure Systems}

Infrastructure systems include equipment such as roads, utilities and sewage and waste management. Accordingly, the most vital equipment that should be available in an earthquake park in line with landscape standards are a generator, an audio system, hazard warning lights, a water tank and solar energy panels.

While the electricity grid was restored four days after the Chile Earthquake, interruptions continued in some areas [9]. In the cases when electrical energy is unavailable or interrupted, generators that convert energy into electrical energy create a life-saving effect [34]. That is because many headaches are encountered where there is no energy production. Solar energy production and solarpowered illumination constitute the standards of Japan DPP in reducing these problems [35].

It is important to set up centralized audio systems to communicate with evacuees and coordinate emergency responses as well as to broadcast announcements. Hazard 
warning lights placed at high points will assist earthquake victims in finding their way in case of crisis. Downed utility lines are factors that direct people to shelters. The need for water tanks is inevitable in addressing basic necessities and cleansing needs such as bathing, laundry and dishwashing and potable water [31].

\section{Structural Designs}

Structural designs refer to conducting static calculations and designing in line with structural design principles for the proper use of buildings, spaces, roads, furniture and even roadside ground cover and tree.

Water. Manually operated water pumps in case water lines are cut off, water tanks for filling and emergency water supply tanks, firefighting and water supply pools are an important structural design in making the lives of the displaced easier and address their needs [3]. The presence of water in parks, supply tanks and pumps are critical features as indicators of post-disaster open space utilization. The availability of water is also important for extinguishing fires.

Food. In Tokyo and Kôbe, both large DPPs and municipal parks have benches or seating that is designed to convert into wood-burning stoves or cooking pits whenever the seat tops are removed. Chileans suffered food and water shortages after the temblor that struck the country in 2010. Vegetable gardens have been an important source of food, especially for those who managed to escape from urban to rural areas. Rokko Kaze No Sate Koen selected edible tree species in the Kôbe design, whereby attempting to address sustenance needs after the disaster [9].

Lighting. León and March (2014) defined three types of lighting that play a role in guiding people to safety in an emergency: lights which are found in safe open areas, solarpowered street lighting, and auxiliary ground lighting which directs people to open spaces [26]. In structural design, the lighting layout is used for night security, function and requirement purposes, and it should be positioned in a way that does not restrict the movement area and hinder passage in designs [36].

Finding Direction and Communications. Signs and street furniture are used as visual points of bearing to ensure evacuees' access to the area they wish to go after an earthquake. In the aftermath of the 1995 Great Hanshin-Awaji Earthquake, victims experienced confusion due to the lack of direction signs and placards [17]. The Massachusetts Institute of Technology designed a network of illuminated landmarks to be distributed throughout the city for post-disaster use. While this structural design is an interactive piece of furniture in daily use, it is used for finding direction and communications during evacuation [33].

Seating Ensembles. It is possible to encounter seating ensembles in various manners in downtowns, parks and walkways. The usefulness of a sitting unit is positively related to its size. Seating units in the earthquake park should be ergonomically functional [37]. While seating arrangements made of shaded and soft surface material provide comfort, multi-functional seating elements that can be turned into tents and ovens for cooking by covering them with tarps can be used according to the need in the earthquake aftermath [38].

Trash Receptacles. Trash receptacles of different sizes and structures can be used to prevent pollution of outdoor spaces.

Management and Computer Centre. A management and computer centre is established to ensure the recording of all kinds of information, communications and internet access during a crisis [39].

Playfields. While the amphitheatre which is used for entertainment, sports and a playground prior to the disaster can be used as a place to assemble and make announcements after the earthquake, paten skate park ramps can be used as an auxiliary element in offloading the necessary equipment and materials from vehicles. As was seen in the Gölcük Earthquake example, an ice-skating rink was used as a temporary morgue. Basketball courts, on the other hand, can be used as emergency hospitals, a meeting spot for a portable kitchen, or as a tent-erecting area [39].

Children's playgrounds. Playgrounds are important in terms of both reverting back from the abnormal situation experienced during the aftermath recovery phase to normal daily lives as well as mental health [40]. In their 2015 study, Kinoshita and Woolley found that adventure playgrounds helped to relieve mental stress, particularly in overcoming shocking natural events such as earthquakes and tsunamis. This is because children are not the same as adults in expressing their emotions, and their mental health care should not be ensured with just a counsellor, but also through play environments as well [41].

Restrooms: In case of disasters, 'manhole toilets,' which are used in earthquake parks and do not have any utilization problem even if utility infrastructure lines are severed, are turned into a toilet, by removing the manhole and covering them up with a tarp.

\section{Planting Designs}

The presence of low-canopy trees and shrubs which hinder access and the setting up of shelters may have an adverse effect on the land use in the aftermath of an earthquake [3]. Refractory vegetation with high water retention, such as sedum should be used around park areas instead of flammable species such as Juniperus spp. and Taxus spp. [42].

Whether their buildings are damaged or not, evacuees still seek shelter and protection in outdoor green spaces due to the deep psychological effects of the earthquake [43]. Thus, it is very crucial to design outdoor green areas 
such as sports halls of various sizes, earthquake parks, squares, which include healthcare services, emergency transportation and strategic plans, to be used for the benefit of society in case of a possible disaster. These areas should be handled as a design input, considering the many functions they take on before and after the earthquake.

When looking at the aftermath functions of each area and their earthquake park components which meet recreational needs in daily life and constitute welfare and lifestyle standards, they indicate how important it is to plan and design such parks before a possible earthquake, their compliance with the criteria, and the forms of organization after the earthquake. Many functions of earthquake parks such as assembly, food and temporary shelter needs which bear vital importance for earthquake victims, first aid, temporary storage, collection and distribution play a key role during and after the disaster.

The aim of this study is to determine the design criteria for earthquake parks by examining in terms of space design the use of earthquake parks in Istanbul's Ataşehir and Topkapı districts which are located in the $1^{\text {st }}$ degree earthquake zone, as pre-earthquake recreation areas as well as disaster parks after the earthquake.

\section{Materials and Method}

\section{A. Purpose of the Study and Defining the Problem}

According to the report of the World Cities Culture Forum (2018), while Oslo (68\%), Singapore (47 \%), Sydney (46\%), Vienna (45\%) and Zurich (41\%) constitute the top five among 38 metropolises with the greatest proportion of green space, Istanbul has the last place with just $2.2 \%$ of green space. Due to insufficient open-green areas in

a

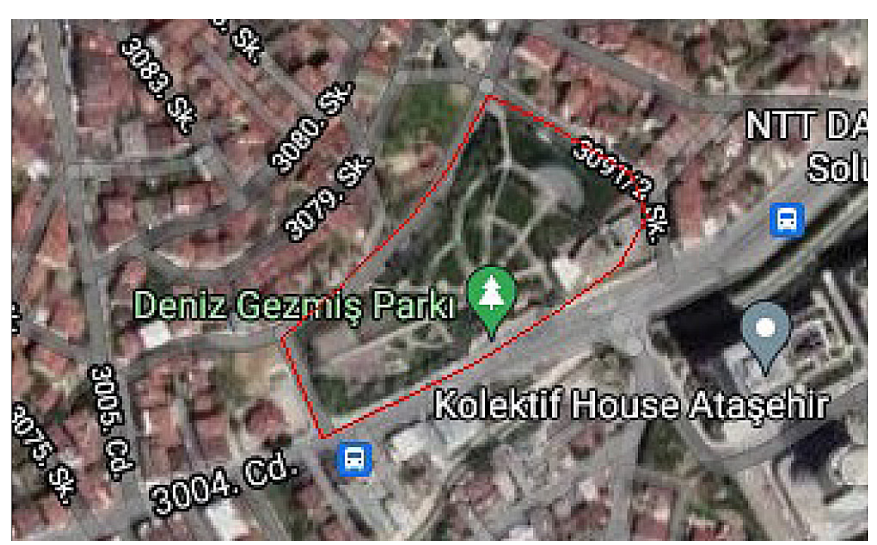

Fig. 1. Earthquake park locations: $a$ - Atașehir; b - Topkapı (Source: print screen from Google maps).
Turkey, high land values in its metropolises and the desire for them to provide income, a growing population due to migration to cities and the organizational legislative structure, the decreased use of outdoor and green areas has deviated from recreational purposes. Parks, squares, sports fields, parking lots, open and green areas should be adequate, accessible and large enough for the population in line with the recreational service they provide to the public before a disaster and after the disaster, whereas these areas should be kept separated and vacant in the zoning plans [44].

The objectives of this study are to find and consolidate existing research regarding the planning and design for seismic resilience from the discipline of landscape architecture and related professions, to make onsite observations at Ataşehir and Topkapı Parks and subsequent assessments of their properties, and come up with suggestions for landscape architects and related vocations to better incorporate seismic resilience into the planning and design of earthquake park areas.

First, within the scope of this study the concept of natural disaster, urban outdoor, green areas and earthquake parks were examined in detail, then standard features that should be readily available at such parks were examined separately as infrastructure space design. In the conclusion section, an assessment is made of the standard features that should be readily available at such parks and recommendations for their implementation are provided. During the literature research and data collection phase, important elements regarding the infrastructure and spatial design of the earthquake parks forming the basis of the study were examined separately. An assessment of emergency use component functions in earthquake parks to be designed for post-earthquake utilization has also been conducted.

b

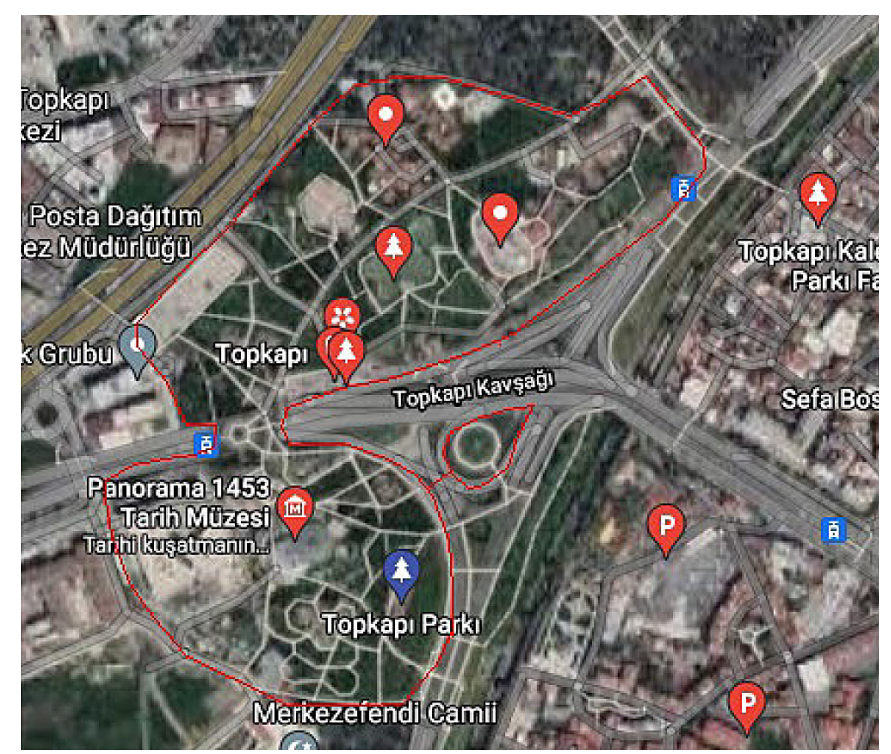


TABLE I

Visual Analysis of Atașehir and Topkapı Parks (Photos by authors)

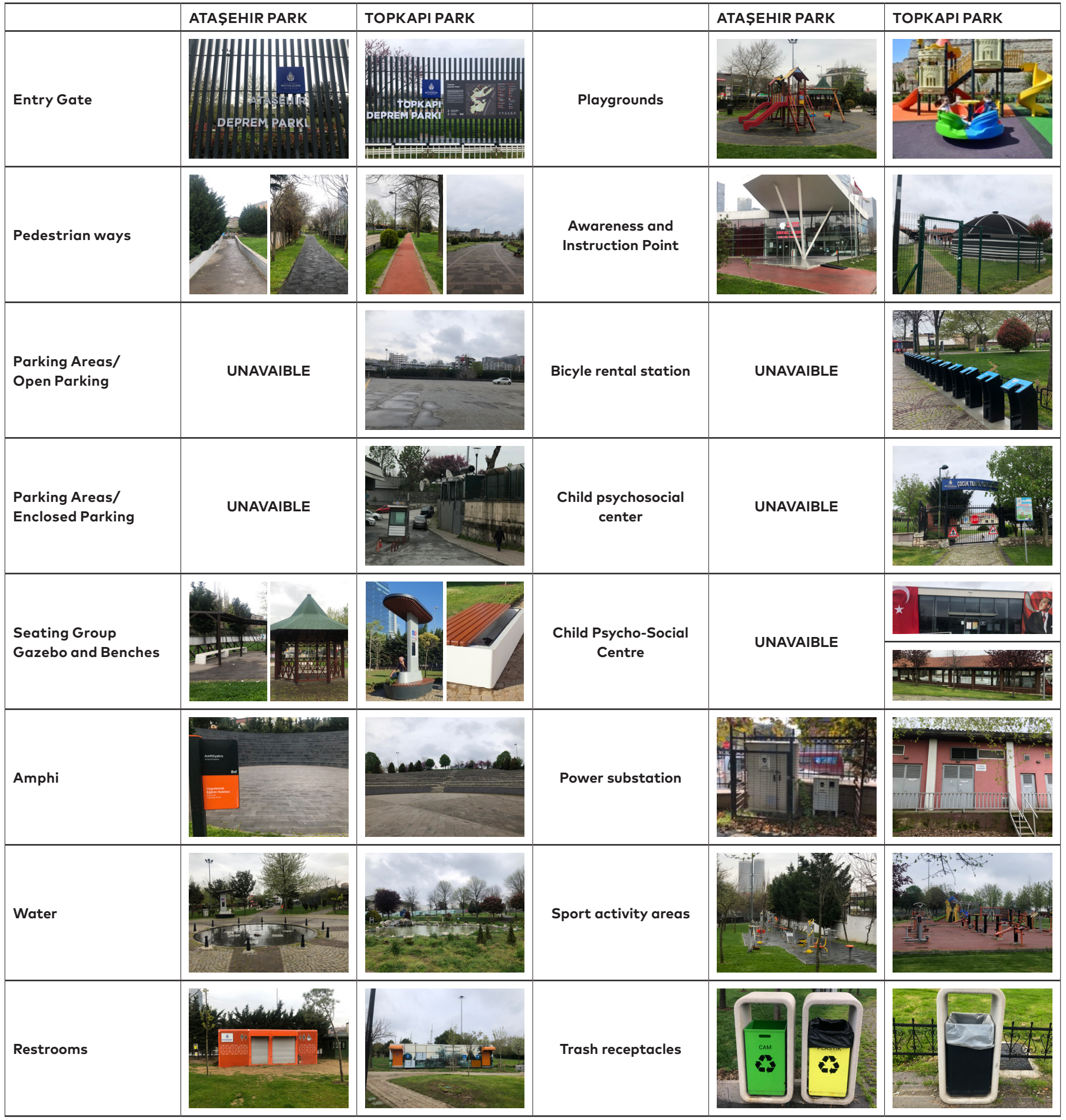

Atașehir Deniz Gezmiș on the Anatolian side of Istanbul and Topkapı Earthquake Parks on the European side were opened on August 17, 2020. It is planned that both earthquake parks will function as a pre-disaster education and cultural centre, and after the disaster, they will function as in-park furniture, tents and food distribution areas and temporary shelter areas.
The size of Atașehir Earthquake Park is $19000 \mathrm{~m}^{2}$, it is located in Ataşehir District's Mustafa Kemal neighbourhood and is very important as a single earthquake park with emergency usage functions. The Ataşehir Earthquake Park features a $700 \mathrm{~m}^{2}$ amphitheatre, a 500-m long running track, a soccer pitch, a basketball court, jogging areas, children's playgrounds, 
sports fields, landscaped recreation and green areas, electricity and lighting systems, as well as automatic sprinkler systems [45]. Located in Mustafa Topkapı neighborhood of Fatih district, the Topkapı Earthquake Park measures $21500 \mathrm{~m}^{2}$. While the Ataşehir Earthquake Park can handle average $500-700$ people after a disaster, Topkapı Earthquake Park can accommodate 5000 people (Table I) [46].

\section{B. Method}

Before deciding on the parks and design issues to be selected within the scope of the study, the analyses of the important earthquake parks from the world and Turkey were made (Table II). Then field analyses were conducted at selected earthquake parks with on-site determinations by applying data collection, analysis, synthesis and evaluation processes. In determining the park's current general condition, shortcomings in existing facilities and parking maintenance problems were defined; whereby an attempt was made to suggest ways to make the existing earthquake parks more compatible with the principles of landscape design (Fig. 2).

\section{Research Findings}

Considering the land location and suitability criteria of both parks, it has been determined that the green area

TABLE II

Earthquake Park Design Issues [47]

\begin{tabular}{|c|c|c|c|c|c|c|c|c|c|c|c|c|}
\hline & 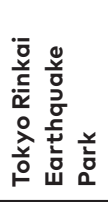 & 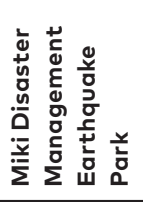 & 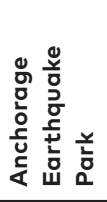 & 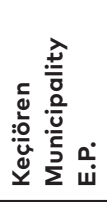 & 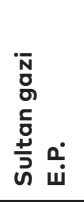 & 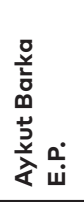 & 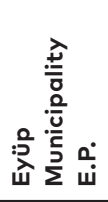 & 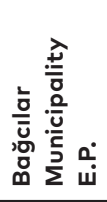 & 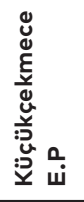 & $\begin{array}{l}\stackrel{0}{u} \\
\dot{0} \\
\text { o }\end{array}$ & 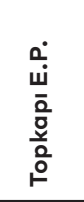 & 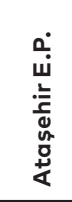 \\
\hline $\begin{array}{l}\text { Total area } \\
\text { (decare) }\end{array}$ & $\stackrel{\sim}{\sim}$ & $\stackrel{\text { N }}{N}$ & $\stackrel{\oplus}{\stackrel{+}{r}}$ & & $\stackrel{n}{\sim}$ & & & & & 으 & 으 & 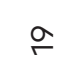 \\
\hline Construction stage & 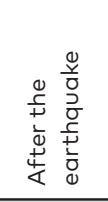 & 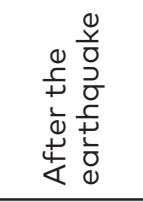 & 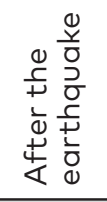 & 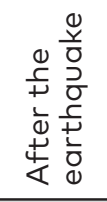 & 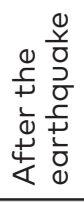 & 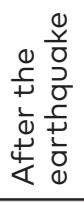 & $\begin{array}{l}0 \\
d \\
\frac{1}{c} \\
\frac{0}{2}\end{array}$ & $\begin{array}{l}0 \\
d \\
\frac{1}{c} \\
\delta \\
0 \\
0\end{array}$ & $\begin{array}{l}0 \\
d \\
\frac{1}{0} \\
\frac{1}{2} \\
\frac{2}{2}\end{array}$ & $\begin{array}{l}\frac{D}{d} \\
\frac{1}{c} \\
\frac{d}{2} \\
\frac{a}{2}\end{array}$ & 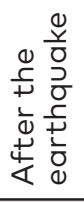 & 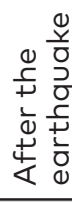 \\
\hline $\begin{array}{l}\text { Earthquake simulation } \\
\text { area }\end{array}$ & + & & & + & + & + & + & + & + & + & + & + \\
\hline Cafeteria and buffet & + & & + & + & + & + & + & + & + & + & + & + \\
\hline Parking & + & + & + & + & + & + & + & + & + & + & + & + \\
\hline Heliport & + & + & . & . & + & + & + & & + & . & + & \\
\hline Picnic area & + & & + & + & + & & + & + & + & + & + & + \\
\hline$W C$ and sink & + & + & + & + & + & + & + & + & + & + & + & + \\
\hline Shower & + & + & + & + & + & + & + & + & + & + & + & + \\
\hline $\begin{array}{l}\text { Garbage collection area } \\
\text { (trash bins) }\end{array}$ & + & + & + & + & + & + & + & + & + & + & + & + \\
\hline $\begin{array}{l}\text { Gathering area/concert/ } \\
\text { festival area/ amphitheatre }\end{array}$ & + & & & + & + & + & + & + & + & & + & + \\
\hline Sport areas & & + & & + & & + & & & & & & \\
\hline Walking path & & & + & & & & & & & & & \\
\hline Bicycle path & & & + & & & & & & & & & \\
\hline Fountain & + & & + & + & + & + & + & + & + & + & + & + \\
\hline Changing room & & & & & + & & & & & & & \\
\hline Playground & & & & + & & + & + & + & + & + & + & + \\
\hline Water tank & + & & & & & & + & & + & & & \\
\hline Medical room & + & + & & & & & & & + & & & \\
\hline $\begin{array}{l}\text { Solar energy/ } \\
\text { generator room/solar }\end{array}$ & & + & & + & + & + & + & + & + & + & & \\
\hline $\begin{array}{l}\text { Communication system } \\
\text { (central) }\end{array}$ & + & & & & & & & & & & & \\
\hline
\end{tabular}




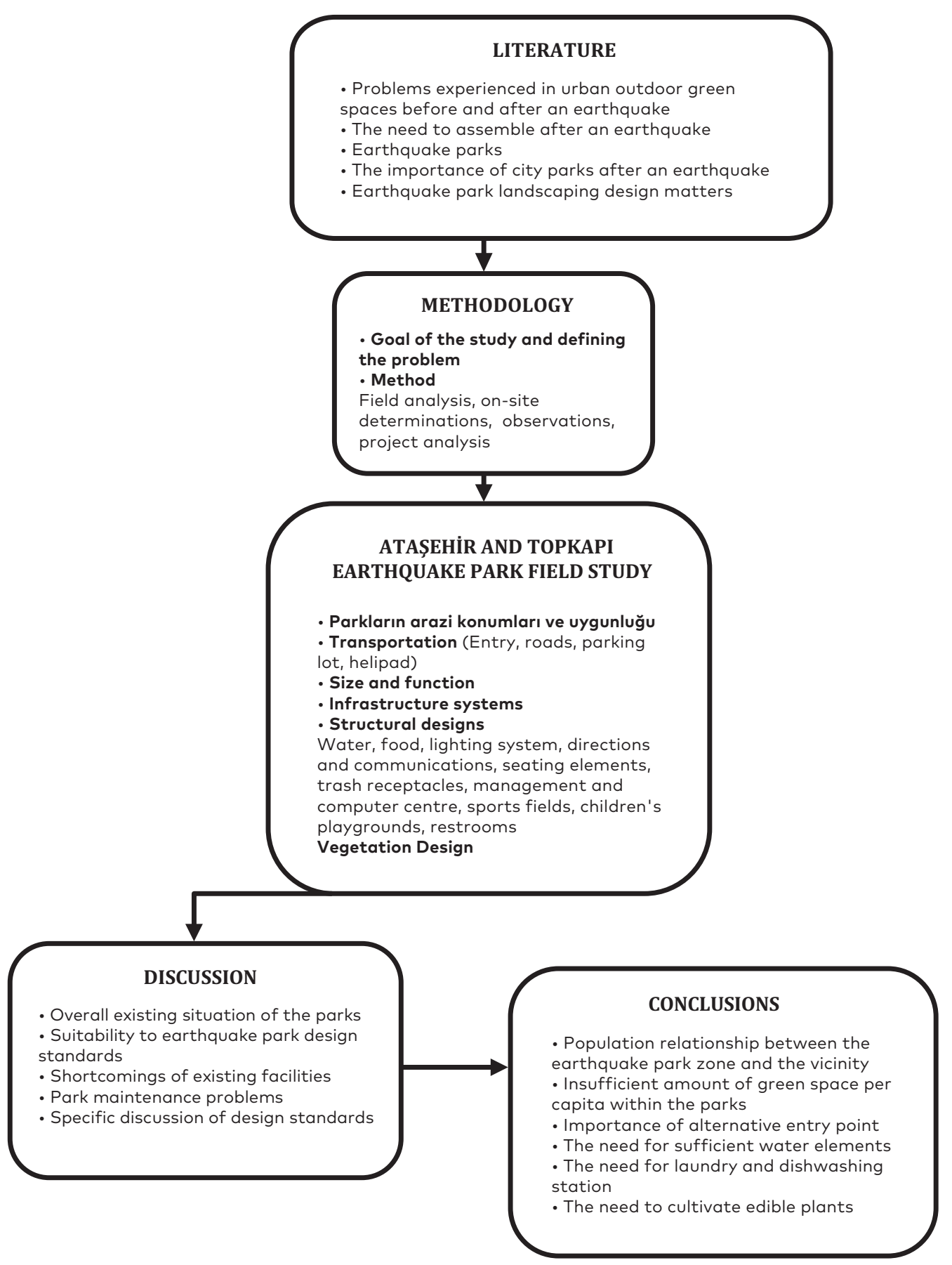

Fig. 2. Flow-chart of analysis (improved by authors).

per capita for both parks is insufficient and there is neither any risk of falling buildings nor secondary hazards around the parks (Table III).

In terms of transportation, it is determined that both park entrances are obstacle-free, that there is an entrance from the non-entry area at Atașehir Park, that vehicles can reach a certain spot from there, that emergency vehicles do not have trouble-free access, that there was an insufficient parking lot and no helipad.

Neither of the parks has a wastewater system although there are smart benches and lighting arrangements with charge points, there is a lack of solar panels.
It was determined that the use of water elements in different ways and rainwater collection systems were not incorporated at Ataşehir Park. There are four mosques in the immediate vicinity of Topkapı Park. There are fountains and common area ornamental pools which are deemed suitable for potable water use.

While there are sufficient places to sit at Ataşehir Park, the same cannot be said for Topkapı Park. In particular, it was observed that Topkapı Park lacked sufficient protection from the sun and wind.

Entrances are evident at both parks for those using the park for the first time. Signs with information 


\section{TABLE III}

\section{Results of Control List Application on the Earthquake Parks (improved by authors)}

\begin{tabular}{|c|c|c|}
\hline \multirow[t]{2}{*}{ DESING STANDARDS } & $\begin{array}{c}\text { ATAȘEHIR } \\
\text { PARK } \\
\end{array}$ & $\begin{array}{c}\text { TOPKAPI } \\
\text { PARK } \\
\end{array}$ \\
\hline & YES/NO & YES/NO \\
\hline \multicolumn{3}{|l|}{ SITE LOCATION AND SUITABILITY } \\
\hline At least $200 \mathrm{~m}$ or 15 minutes walking distance from the buildings to the assembly area & YES & YES \\
\hline $6 \mathrm{~m}$ wide street facing the park (Disaster Reduction and Human Renovation Institution (1997) & YES & YES \\
\hline Risk of falling buildings & NO & NO \\
\hline Possibility of secondary danger & NO & NO \\
\hline Any security zone, including fire alarms, surrounding the park & NO & NO \\
\hline Shelter or building that can be used for an emergency & YES & YES \\
\hline Ground slope suitability & YES & YES \\
\hline Floor that can lift heavy vehicles such as fire brigade, ambulance, aid vehicles & YES & YES \\
\hline Proximity to basic facilities such as hospitals & YES & YES \\
\hline \multicolumn{3}{|l|}{ TRANSPORTATION } \\
\hline Entrance door prominence & YES & YES \\
\hline Appropriateness of entrance door width & YES & YES \\
\hline Entrance affected by barriers & NO & NO \\
\hline Possibility to enter the park from the non-entry area & NO & YES \\
\hline Another barrier-free entry & NO & YES \\
\hline Possibility of using ambulances and fire trucks & NO & YES \\
\hline Separated pedestrian and bicycle paths & NO & NO \\
\hline Transportation options such as bus, train, car, bicycle to reach the park & YES & YES \\
\hline Bus stop near the park & YES & YES \\
\hline Traffic lights to guide traffic density and speed limits on park roads & YES & YES \\
\hline Well-designed footpath connections to ensure pedestrian safety & YES & YES \\
\hline Sufficient parking space & NO & YES \\
\hline Helipad 8 for multi-use park 330' × 330') & NO & YES \\
\hline \multicolumn{3}{|l|}{ SIZE AND FUNCTION } \\
\hline Area per person $2 \mathrm{~m} 2$ area (JICA, 2002) & NO & NO \\
\hline Hybrid parking feature & YES & YES \\
\hline Shelter or building that can be used for an emergency & YES & YES \\
\hline \multicolumn{3}{|l|}{ INFRASTRUCTURE SYSTEMS } \\
\hline Flashers to assist in finding directions at high points & YES & YES \\
\hline Water tank & YES & YES \\
\hline Wastewater systems & NO & NO \\
\hline Wastewater systems A solar panel or other backup for power & NO & NO \\
\hline \multicolumn{3}{|l|}{ STRUCTURAL DESIGNS } \\
\hline The feature of having any water in the entrance & YES & YES \\
\hline Different uses of the water element in the parking lot & NO & NO \\
\hline Rainwater collection barrel or other facility to provide water supply & NO & NO \\
\hline A bucket or pump to extinguish fires and convey water & NO & NO \\
\hline Fire extinguisher & NO & NO \\
\hline Any office to transmit and manage information & YES & YES \\
\hline Enough places to sit & YES & NO \\
\hline properly placed seating & YES & NO \\
\hline Sun, shade and wind protection possibilities & YES & NO \\
\hline Light system at the entrance of the park & YES & YES \\
\hline
\end{tabular}




\begin{tabular}{|c|c|c|}
\hline Light system up to the end of the open area & YES & YES \\
\hline Parking plan for first time users & YES & YES \\
\hline A well-marked guidance system within the park & YES & YES \\
\hline Benches that can turn into grills that allow evacuees to cook & YES & NO \\
\hline Management and Computer center & YES & YES \\
\hline $\begin{array}{l}\text { Sports halls or similar space that can be used as a place to set up large tents, } \\
\text { a meeting point for a portable kitchen or an emergency hospital }\end{array}$ & YES & YES \\
\hline Children's playgrounds & YES & YES \\
\hline Manhole toilets & YES & YES \\
\hline Garbage Collection Area & YES & YES \\
\hline Lost \& Found assembly area & YES & YES \\
\hline Laundry and dishwashing & NO & NO \\
\hline Health Room & NO & NO \\
\hline \multicolumn{3}{|l|}{ PLANTING DESIGNS } \\
\hline Combinations of short and tall trees & YES & YES \\
\hline Edible plants & NO & NO \\
\hline Arrangement and care of trees and shrubs & YES & YES \\
\hline
\end{tabular}

and directions and signboards with plans are clearly visible.

Benches that can be converted into hearths are found at Ataşehir Park, but not at Topkapı Park. It was also determined that there are sports halls which may be used as a large tent assembly point, a portable kitchen or emergency hospital at Ataşehir Park, but not at Topkapı Park. There are healthcare wards at Ataşehir Park under the name 'Family Healthcare Centre', while there are plans underway for a section of the parking lot to be used as an infirmary at Topkapı Park.

In case of disaster, the Erdal Eren Cultural Centre at Ataşehir Park will be used as an 'Awareness and Instruction Point,' whereby the amphitheatre will be used as an 'Applied Training Point.' Again, in case of a disaster, the Turkish World Culture District at Topkapi Park will be converted into a 'Disaster Management Campus,' and the amphitheatre will be utilized as an 'Aftermath Reorientation Zone'. The Istanbul City Museum will be turned into a Communications Coordination Centre; the IMM Child Traffic Education Park will be turned into a Child Psychosocial Centre, the area of IMM European Side Parks and Gardens Directorate of the Fatih Regional Supervisory Office is planned to be used as an 'Aftermath Logistics Centre'. In the light of this data, it was seen that the conditions at Topkapı Earthquake Park were more suitable for implementing the 's disaster management plans.

Both parks have enclosed areas to address the heating needs of earthquake victims taking shelter during the aftermath. In particular, there are four mosques in the immediate vicinity of Topkapı Earthquake Park which may be used to address heating and shelter needs.

It has been determined that the cultivation of edible plants is insufficient in both parks, whereas the use of different plant species and their care is sufficient.
The designs of the garbage collection zones and garbage trash receptacles at both parks were observed to be suitable and of sufficient numbers.

\section{Discussions and Recommendations}

Due to the limitation of research conditions and the difficulty of obtaining some of the data, just two city earthquake parks in Istanbul could be studied during the research phase. For future research, relevant information needs to be collected, the number of examples should be increased and more earthquake park areas should be applied to the assessment system of this study.

With Ataşehir Park, which was visited at irregular intervals, it was observed during the first visit that the urban furniture was worn down due to usage and inclement weather, while during subsequent visits it was noticed that they had either been repaired or replaced. While the seating elements are used in different ways in the city, pedestrian areas, and parks, they need to be functional for earthquake parks. While the seating elements at Ataşehir Earthquake Park are of a design suitable for use in the aftermath of a disaster, it has been observed that the seats at Topkapı Park are neither functional nor aesthetic. Both parks feature recreational areas such as sports activity areas, cultural centres, libraries and mosques to address needs such as erecting tents, portable kitchens, and emergency hospitals. Nevertheless, considering the population density and traffic problems of Istanbul, it is also a serious problem that there is no helipad at Atașehir Park, which is important for earthquake parks in emergencies that require short travel time. Again, it is observed that children's playgrounds, which are effective during aftermath psychological recovery, are insufficient 
in both parks. However, there are plans to turn the İBB Children's Traffic Education Park at Topkapı Earthquake Park into a Child Psychosocial Centre, which is bound to play an important role in terms of psychological support for children after an earthquake.

While observations regarding the Ataşehir Earthquake Park include a lack of space per capita, inadequate parking lot, inadequacy of vegetation designs, ill-designed playgrounds from the standpoint of use and quality, obstacles at the entrance preventing air and land emergency vehicles from entering the area, shortcomings pertaining to the Topkapı Earthquake Park include space per capita, vegetation designs and seating elements. Finally, the fact that both parks are near residential areas, education facility areas, business centres, and healthcare centres may cause more demand than their pre-earthquake utilization. Based on the research observations, it is forecast that both the infrastructure systems and structural designs will remain inadequate, depending on the density of the population to be served. Thus, the importance of building areas suitable for these features is comprehended once more during the process of designing earthquake parks by considering the standard features that need to be incorporated. As a result of the study, it was ascertained that unlike traditional parks, designing earthquake parks according to determined criteria is important for post-disaster use.

According to the research findings, there are inequalities in the number and size of the earthquake parks versus the population to be served. As for location assessment, the majority of neighbourhoods are within walking distance. Parking areas are used on a daily basis. There is a need for studies on portable or multi-functional urban furniture, potable water resources, and sanitary and renewable energy sources in the existing assembly areas. VD Shrestha in his investigative study regarding open spaces and seismic risk perception through the analysis of people's reactions during and after the 2015 Nepal Earthquake argued that open spaces have a direct or indirect impact on people's perception of seismic risk. He indicated that medium-sized common areas of about $200 \mathrm{~m}$ are preferred as safe havens and that, while the availability of necessary infrastructure and services affects the preferred situation, it is an important component of disaster response.

As is the case throughout Istanbul, the lack of green space per capita at both parks was an expected result. The matter of increasing green areas inside the parks is particularly vital considering the countless studies that emphasize the importance of their use in the aftermath of an earthquake [48]. It is important to plan a 'second city' that offers diverse uses and experiences, so professionals involved in the design of these areas may design multifunctional landscapes for both recreational activities and dealing with natural disasters.

According to Akdur (2001), it should be taken into consideration that the post-earthquake shelter area may bear other disaster risks caused by the earthquake and it should be a safe zone [28]. Areas with a safe morphological structure and bearing the risk of landslides, floods, tsunamis and swamps should not be preferred as an earthquake park zone. The absence of the risk of buildings falling around either park or other earthquake caused risks is important for the safe usage of the parks during the disaster aftermath. Fatih and Ataşehir districts are indicated as first-degree risk districts when looking at the map showing the fault lines in Istanbul. Although Ataşehir earthquake park has afunctional transformation in terms of equipment and elements, and Topkapı has a functional transformation in terms of equipment, elements and area, from a geomorphological, geological and geotechnical point of view. Being on fault lines does not show the characteristics of a safe place.

The absence of an alternative entry point at the Ataşehir Park may have negative consequences for aftermath use of the park. In this context, there is a need to provide entry alternatives. Once again, the restricted use of emergency vehicles at Ataşehir Park is a very significant handicap. Roads in the vicinity of earthquake parks, emergency rescue, evacuation, medical aid, information assembly, etc. after an earthquake are primary influential factors in their matters. Considering the problems in traffic management and administrative structuring throughout Istanbul, vehicle parking on the roads poses a major problem. Entry and exit manoeuvres to the parking lot greatly reduce the usage capacity of roads and emergency access roads [49]. Having insufficient parking spaces at Ataşehir Park will become a bigger headache with unplanned parking hassles. Moreover, another serious problem is the lack of a helipad, which is vital for earthquake parks in emergencies that require short travel time.

The existence of wastewater systems and alternative energy sources on demand is important in both parks. The shortage of water elements around both parks is detrimental in terms of both sustenance and responding to fires that may occur after the earthquake.

The low number of seats at Topkapı Park will inevitably have a negative effect on usage during the aftermath of the earthquake. The number of seats needs to be increased urgently. The lack of benches that can be converted into cooking spaces at the Topkapı Earthquake Park, like the ones in many earthquake parks in Japan, will pose a problem in addressing food needs during the aftermath of an earthquake.

Again, neither park offers any effective laundry and dishwashing services that would be beneficial in returning to normal life after the earthquake. There is an urgent need to tackle these needs for both parks. Suitable places for such needs are found particularly at Topkapı Park. While the areas to address restroom needs are available in both parks, planning should be made that would address the heavy traffic during the aftermath of the disaster. 
Finally, considering the topic of vegetation, the need to cultivate edible plants was seen at both parks. Additions to planting designs will be important in terms of addressing nutritional needs of disaster victims during the earthquake aftermath. In the Rokko Kaze No Sate Koen Park, by estimating the needs during the aftermath, edible fruit tree species were selected in plant designs [50].

\section{Conclusions}

Due to the fact that people tend to flee their places after an earthquake for open and safe areas amid the possibility of continuing aftershocks, emergency response plans, first aid and temporary shelter areas are of great importance. In this context, earthquake parks take on a key role in mitigating damage caused by the earthquake by addressing the needs of people such as ensuring the safety of their lives and property, sheltering, accommodations, food and beverage. As a result of this study, it was determined that site location and suitability, transportation, size and function, infrastructure systems, structural and planting design issues are important issues to be considered in the design of earthquake parks.

Compliance of urban parks with the principles of landscape architecture plays an important role in improving efficiency of the disaster prevention capability of earthquake parks at an urban level. Analysing and evaluating the suitability of the earthquake park system objectively for disaster prevention and risk avoidance and offering suggestions for solving problems by identifying existing deficiencies is the primary task of earthquake park research. Thereby, this article takes up earthquake parks as a research object and creates a conformity assessment method for earthquake parks and disaster prevention and risk avoidance in particular. Based on previous research, through rigorous logical reasoning and careful choice of indicators, this study creates a framework for the disaster prevention capacity assessment of urban park systems that were applied at earthquake parks found in Istanbul's Ataşehir and Fatih provincial districts.

It should be a priority to evaluate earthquake parks according to the population density, ease of transportation and the quality of the vicinity in terms of housing needs. Although the Ataşehir and Topkapı earthquake parks, which constitute the study specimens, have the quality of the area in terms of ease of transportation and housing needs, they have shortcomings in the face of the population density of these districts. Another important issue is to create the conditions that shall ensure effective disaster management. An 'Applied Training Point' and an 'Awareness and Education Point' were created for post-disaster at the Ataşehir Earthquake Park, whereas in addition to these, the Topkapı Earthquake Park features 'Disaster Management Campus', 'Post-Disaster Reorientation Area',
'Communications Coordination Centre' as well as 'PostDisaster Logistics Centre.' Accordingly, it is seen that the conditions created for an effective disaster management at the Topkapı Earthquake Park are more comprehensive than those at the Ataşehir Earthquake Park.

The importance and requirements of earthquake park design criteria were emphasized once again as a result of this study. Although both parks are defined as earthquake parks, they do not adequately meet the earthquake park design criteria defined by international standards, but rather are planned mainly for recreation; hence, it has been determined that they meet mostly perceptual expectations. In this context, the secondary result of this study is that parks designed as recreation areas are bound to be insufficient in terms of enabling people to go about their daily lives during the aftermath of an earthquake. As a supportive resource, this study aims to determine the standard features of both the Ataşehir and Topkapı Earthquake Parks, the former of which is located on the Anatolian side, with the latter situated on the European side of Istanbul, a city that straddles our country's earthquake-prone Marmara Region, as well as emphasizing the importance of constructing areas suitable for these features in the design process which might be needed to be utilized in the aftermath of a destructive earthquake.

\section{REFERENCES}

1. Jayakody, R. R. J. C., Amaratunga, D., Haigh, R. Plan and design public open spaces incorporating disaster management strategies with sustainable development strategies: a literature synthesis. MATEC Web of Conferences, vol. 229, 2018, 04001.

https://doi.org/10.1051/matecconf/201822904001

2. Tan, P. Y., Jim, C. Y. (Eds.). Greening Cities. Springer Singapore, 2017. 372 p.

https://doi.org/10.1007/978-981-10-4113-6

3. French, E. L., Birchall, S. J., Landman, K., Brown, R. D. Designing public open space to support seismic resilience: A systematic review. International Journal of Disaster Risk Reduction, vol. 34, 2019, pp. 1-10.

https://doi.org/10.1016/j.ijdrr.2018.11.001

4. Tidball, K. G., Krasny, M. E., Svendsen, E., Campbell, L., Helphand, K. Stewardship, learning, and memory in disaster resilience. Environmental Education Research, vol. 16, no. 5-6, 2010, pp. 591-609.

https://doi.org/10.1080/13504622.2010.505437

5. Nakabayashi, I. Urban planning based on disaster risk assessment. In: Disaster Management in Metropolitan Areas for the 21st Century, Proceedings of the IDNDR Aichi/Nagoya International Conference, 1-4 November, 1994, Nagoya, Japan, UNCRD Proceedings Series, No. 1. Nagoya, Japan: United Nations Centre for Regional Development, pp. 225239.

6. Wesener, A. Growing resilient cities: Urban community gardens and disaster recovery after the 2010/11 Canterbury/ 
Christchurch earthquakes. In D. Brantz, A. Sharma eds. Urban resilience in a global context: Actors, Narratives and Temporalities, Bielefeld: Transcript Verlag, 2020, pp. 77-101. https://doi.org/10.14361/9783839450185-005

7. Wei, Y., Jin, L., Xu, M., Pan, S., Xu, Y., Zhang, Y. Instructions for planning emergency shelters and open spaces in China: Lessons from global experiences and expertise. International Journal of Disaster Risk Reduction, vol. 51, 2020, 101813. https://doi.org/10.1016/j.ijdrr.2020.101813

8. Brantz, D., Sharma, A. (Eds.). Urban Resilience in a Global Context: Actors, Narratives, and Temporalities. Bielefeld: transcript Verlag, 2020. 250 p. https://doi.org/10.14361/9783839450185

9. Allan, P., Bryant, M., Wirsching, C., Garcia, D., Rodriguez, M. T. The influence of urban morphology on the resilience of cities following an earthquake. Journal of Urban Design, vol. 18, no. 2, 2013, pp. 242-262.

https://doi.org/10.1080/13574809.2013.772881

10. Winandari, M. I. R. Public open space for disaster mitigation in Tangerang housing estates. In: IOP Conference Series: Earth and Environmental Science, vol. 106, 2018, 012021. https://doi.org/10.1088/1755-1315/106/1/012021

11. Ishikawa, M. Landscape planning for a safe city. Annals of Geophysics, vol. 45, no. 6, 2002. https://doi.org/10.4401/ag-3544

12. Nira, R. More Parks Can Lessen the Blow of Earthquakes, 2019 [online]. Texas A \& M Today [cited 17.06.2021]. https:// today.tamu.edu/2019/08/13/more-parks-can-lessen-theblow-of-earthquakes/

13. Koren, D., Rus, K. The potential of open space for enhancing urban seismic resilience: A literature review. Sustainability, vol. 11, no. 21, 2019, 5942 . https://doi.org/10.3390/su11215942

14. Brand, D., Nicholson, H. Public space and recovery: learning from post-earthquake Christchurch. Journal of Urban Design, vol. 21, no. 2, 2016, pp. 159-176. https://doi.org/10.1080/13574809.2015.1133231

15. Chan, J., Dubois, B., Tidball, K. G. Refuges of local resilience: Community gardens in post-Sandy New York City. Urban Forestry \& Urban Greening, vol. 14, no. 3, 2015, pp. 625-635. https://doi.org/10.1016/j.ufug.2015.06.005

16. Dionisio, M. R., Kingham, S., Banwell, K., Neville, J. Geospatial tools for community engagement in the Christchurch rebuild, New Zealand. Sustainable Cities and Society, vol. 27, 2016, pp. 233-243.

http://dx.doi.org/10.1016/j.scs.2016.04.007

17. Shiozaki, Y., Nishikava, E., Deguchi, T. (Eds.). Büyük Hanshin Depreminden Alınan Dersler. Istanbul: Istanbul Büyükşehir Belediyesi Basımevi, 2006, 123 p.

18. Allan, P., Bryant, M. The critical role of open space in earthquake recovery: a case study. In: EN: Proceedings of the 2010 NZSEE Conference, 2010, New Zealand, 2010, pp. 1-10.

19. Coburn, A., Spence, R. Earthquake protection, $2^{\text {nd }}$ edition. New York: John Wiley \& Sons, 2002. $424 \mathrm{p}$ https://doi.org/10.1002/0470855185

20. Sariçam, S. Kentsel Açik-Yeşil Alanlarin Afet Sonrasi İșlevleri. GSI Journals Serie B: Advancements in Business and Economics, vol. 2, no. 1, 2019, pp.1-15.
21. Mexico City earthquake of 1985 [online]. Britannica [cited 17.06.2021]. https://www.britannica.com/event/MexicoCity-earthquake-of-1985

22. Nakase, I., Fujimoto, M., Akazawa, H., Mizuno, Y. Park and greenery forms through participation of local residents after Great Hanshin-Awaji Earthquake (Report). Nature and Human activities, 2000, vol. 5, pp. 41-46. https://www. hitohaku.jp/publication/r-bulletin/Nature\%20and\%20 Human\%20Activities\%20No.05\%202000\%20041-046\%20 optimized.pdf

23. Aksoy, Y., Turan, A., C., Atalay, H. İstanbul Fatih ilçesi yeşil alan yeterliliğinin Marmara depremi öncesi ve sonrası değerleri kullanılarak incelenmesi. Uludağ University Journal of The Faculty of Engineering, vol. 14, no. 2, 2009, 137-150. https://dergipark.org.tr/tr/download/articlefile/202722

24. BBC NEWS, 2019 [cited 17.06.2021]. https://www.bbc.com/ turkce/haberler-turkiye-49935494

25. Ogawa, N. Disascape to Preemptive Landscape: Resilient Parks for Earthquake Disaster Management. University of Georgia, Athens, GA. Master Thesis, 2014.

26. León, J., March, A. Urban morphology as a tool for supporting tsunami rapid resilience: A case study of Talcahuano, Chile. Habitat international, vol. 43, 2014, pp. 250-262. https://doi.org/10.1016/j.habitatint.2014.04.006

27. The Sphere Project. Humanitarian Charter and Minumum Standarts in Humanitarian Response, 2011 [online 17.05.2021]. https://www.unhcr.org/50b491b09.pdf https://doi.org/10.3362/9781908176202

28. Akdur, R. Afetlere Hazırlık ve Afet Yönetimi. S. Esin, T. Oğuzhan, K. Kaya, T. Ergüder, 2001 [cited 17.05.2021]. https://www.recepakdur.com/media/1295/09-akdur-rafetlere-hazirlik-ve-afet-yo-netimi-sayfa-1-38.pdf

29. Xu, J., Yin, X., Chen, D., An, Y., Nie, G. Multi-criteria location model of earthquake evacuation shelters to aid in urban planning. International Journal of Disaster Risk Reduction, vol. 20, 2016, pp. 51-62. https://doi.org/10.1016/j.ijdrr.2016.10.009

30. Vanvactor, J. D. Strategic health care logistics planning in emergency management. Disaster Prevention and Management, vol. 21, no. 3, 2012, pp. 299-309. https://doi.org/10.1108/09653561211234480

31. Koçan, N., Sürün, S. 1. Derece Deprem Kuşağında Yer Alan Balıkesir-Burhaniye Kenti İçin Deprem Parkı Önerisi. Nevşehir Bilim ve Teknoloji Dergisi, vol. 9, 2020, pp. 14-31. https://doi.org/10.17100/nevbiltek.681336

32. Nedjati, A., Vizvari, B., Izbirak, G. Post-earthquake response by small UAV helicopters. Natural Hazards, vol. 80, 2016, pp. $1669-1688$. https://doi.org/10.1007/s11069-015-2046-6

33. Mazereeuw, M., Yarina, E. Emergency preparedness hub: Designing decentralized systems for disaster resilience. Journal of Architectural Education, vol. 71, no. 1, 2017, pp. 65-72.

https://doi.org/10.1080/10464883.2017.1260928

34. Çelik, A., Ender, E. Design Principles of Earthquake Park. In R. Efe, I. Cürebal, A. Gad, B. Tóth eds. Environmental Sustainability and Landscape Management. Sofia: St. Kliment Ohridski University Press, 2016, pp. 735-741. 
35. Masuda, N. Disaster refuge and relief urban park system in Japan. Landscape Architecture Frontiers, vol. 2, no. 4, 2014, pp. 52-60.

36. Önal, S. Kent Parklarda Kullanılan Donatıların Standartlara Uygunluğunun Belirlenmesi: Ankara Örneği. Antropoloji, vol. 38, 2019, pp. 54-64.

https://doi.org/10.33613/antropolojidergisi.633411

37. Mumcu, S., Yilmaz, S. Seating furniture in open spaces and their contribution to the social life. In R. Efe, I. Cürebal, A. Gad, B. Tóth eds. Environmental Sustainability and Landscape Management. Sofia: St. Kliment Ohridski University Press, 2016, pp. 169-187.

38. Yücel, G. Earthquake and evacuation area assessment for Istanbul Avcllar district. Disaster Science and Engineering, vol. 4, no. 2, 2018, pp. 65-79.

39. Dönmez, Y. Investigation of Active Green Spaces within the Criterion of Earthquake Park Concept: Case Study of Safranbolu City. In R. Efe, I. Cürebal, A. Gad, B. Tóth eds. Environmental Sustainability and Landscape Management. Sofia: St. Kliment Ohridski University Press, 2016, pp. 585591.

40. Okuyama, M. Recovery from Earthquake for Children (in Japanese), 2021 [online]. Child research net [cited 17.06.2021]. http://www.blog.crn.or.jp/lab/06/15.html

41. Kinoshita, I., Woolley, H. Children's play environment after a disaster: The great East Japan earthquake. Children, vol. 2, no. 1,2015 , pp. 39-62.

https://doi.org/10.3390/children2010039

42. Fire Resistant Plants for Chelan/Douglas County Washington. Master Gardener Program, 2017 [cited 17.06.2021]. https://s3.wp.wsu.edu/uploads/ sites/2086/2018/01/fireresistantplants2017.pdf

43. Çoban, M., Sözbilir, M., Göktaş, Y. Deprem deneyimini yaşamış kişilerin deprem öncesi hazırlık algılarının belirlenmesi: Bir durum çalışması. Doğu Coğrafya Dergisi, vol. 22, no. 37, 2017, pp. 113-134. https://doi.org/10.17295/ataunidcd.281721

44. Özkir, A. Kent Parkları Yönetim Modelinin Geliștirilmesi. Ankara Üniversitesi. Fen Bilimleri Enstitüsü, Peyzaj Mimarlığı Anabilim Dalı, Doctoral Thesis, 2007. https:// dspace.ankara.edu.tr/xmlui/handle/20.500.12575/34072

45. Deniz Gezmiș Parkı, 2021 [online]. Ladin [cited 17.06.2021]. http://www.ladin.gen.tr/project/deniz-gezmis-parki

46. IBB, 2021 [online, cited: 17.06.2021]. https://www.ibb. istanbul/News/Detail/37124

47. Kurt Konakoğlu, S. S., Çelik, K. T. Afet ve Acil Durum Toplanma Alanı Olarak Belirlenen Parkların Deprem Parkı Olabilirliklerinin Amasya Kenti Örneğinde Değerlendirilmesi. International Social Sciences Studies Journal, vol. 7, no. 81, 2021, pp. 1740-1755. https://doi.org/10.26449/sssj.3092

48. Villagra-Islas, P., Alves, S. Open space and their attributes, uses and restorative qualities in an earthquake emergency scenario: The case of Concepción, Chile. Urban Forestry \& Urban Greening, vol. 19, 2016, pp. 56-67. https://doi.org/10.1016/j.ufug.2016.06.017

49. Buldurur, M. A., Kurucu, H. İstanbul'da Afet Yönetimi ve Acil Ulaşım Yollarının Değerlendirmesi. Planlama Dergisi, vol. 25, no. 1, 2015, pp. 21-31.

https://doi.org/10.5505/planlama.2015.47965
50. Bryant, M., Allan, P. Open space innovation in earthquake affected cities. In Earthquake Affected Cities, Approaches to Disaster Management - Examining the Implications of Hazards, Emergencies and Disasters, John Tiefenbacher, IntechOpen, 2013. https://doi.org/10.5772/55465

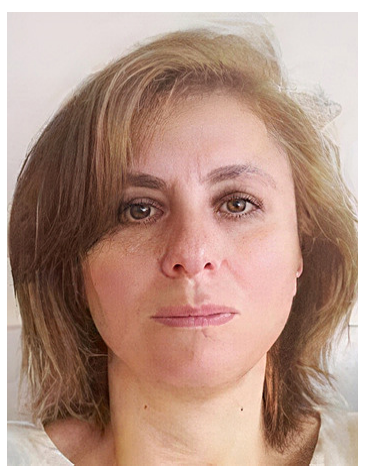

Gökçen Firdevs Yücel Caymaz, Assoc. Prof. Dr Aydin University, İstanbul. Dr Yücel is the Vice President of Architecture Department of İstanbul Aydin University. She received her BArch from Istanbul University and MSc in Landscape Planning Program from Istanbul Technical University. She earned her PhD degree in Landscape Planning Program from Istanbul Technical University. Her major research interests are landscape design, environmental perceptions and street furniture. Since 2015, she has been an Associate Editor of A+Arch Design journal of the Architecture and Design Faculty of İstanbul Aydin University. Dr Yücel has published in her areas of expertise in national and international journals, congresses, and international book chapters.

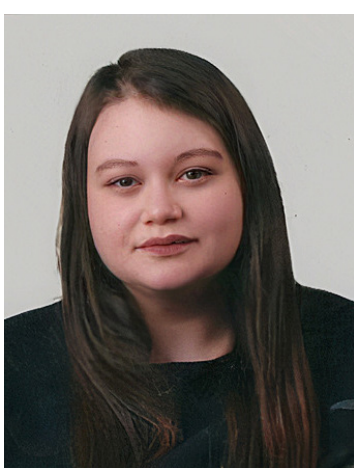

Hümeyra Komar graduated from the Department of Architecture of Istanbul Aydın University, Turkey. She is studying for her master's degree in the Department of Architecture of Istanbul Aydın University. She has been working on projects as an architect and 3D designer for 2018.

\section{Contact Data}

\section{Gökçen Firdevs Yücel Caymaz}

Faculty of Architecture and Design, Istanbul Aydın University, Istanbul, Turkey

E-mail: gokcenfyucel@aydin.edu.tr

ORCID iD: https://orcid.org/0000-0002-0012-8384

\section{Hümeyra Komar}

Institute of Science, Istanbul Aydın University, Istanbul, Turkey

E-mail: humeyrakomar@stu.aydin.edu.tr 